\title{
Evolution and Relationships of the Conifer Seed Cone Telemachus: Evidence from the Triassic of Antarctica
}

by Ignacio H. Escapa, Anne Laure Decombeix, Edith L. Taylor, and Thomas N. Taylor

2010

This is the published version of the article, made available with the permission of the publisher. The original published version can be found at the link below.

[Citation]

Published version: http://www.jstor.org/stable/10.1086/651948

Terms of Use: http://www2.ku.edu/ scholar/docs/license.shtml 


\title{
EVOLUTION AND RELATIONSHIPS OF THE CONIFER SEED CONE TELEMACHUS: EVIDENCE FROM THE TRIASSIC OF ANTARCTICA
}

\author{
Ignacio H. Escapa, ${ }^{1}$ Anne-Laure Decombeix, Edith L. Taylor, and Thomas N. Taylor \\ Department of Ecology and Evolutionary Biology and Natural History Museum and Biodiversity Institute, \\ University of Kansas, Lawrence, Kansas 66045-7600, U.S.A.
}

\begin{abstract}
The seed cone Telemachus is known from several Triassic localities in Gondwana. New specimens from two localities in Antarctica provide additional information about the type species, Telemachus elongatus, based on details of morphology and anatomy revealed by using a modified transfer technique on the compressed plants. Seed cones of T. elongatus are up to $6.0 \mathrm{~cm}$ long and characterized by conspicuous, elongate bracts. A second Antarctic species, described here as Telemachus antarcticus, is segregated, based on a shorter bract and differences in cone size. Newly recognized features of the genus include the shape, size, and disposition of the ovules; vascularization of the ovuliferous complex; and scale and bract histology. As a result of this new information, it is now possible to compare Telemachus with the permineralized Middle Triassic conifer seed cone Parasciadopitys from the Central Transantarctic Mountains. The similarities between the two genera make it possible to relate organs in different preservational modes and to develop a more complete concept for this widely distributed Gondwana conifer. Placing the Telemachus plant within a phylogenetic context makes it possible to evaluate the relationship with other so-called transitional conifers, an informal group that has been interpreted as intermediate between Paleozoic and modern conifers.
\end{abstract}

Keywords: Triassic, Antarctica, conifers, Telemachus, evolution.

Online enhancement: appendix.

\section{Introduction}

The conifer Telemachus was originally erected by Anderson (1978) for isolated seed cones from the Middle Triassic of South Africa that were associated with broad, multiveined leaves assigned to different form genera, e.g., Podozamites, Heidiphyllum, or Desmiophyllum. The genus was subsequently discovered in a number of localities throughout Gondwana, including the Middle Triassic of New Zealand (Retallack 1981), Antarctica (Yao et al. 1993; Axsmith et al. 1995, 1998), Argentina (Morel 1994; Lutz 2006), and Chile (Nielsen 2005). As a result of these reports, Telemachus represents the most widely distributed conifer seed cone from the Triassic of Gondwana. Despite the wide geographic and stratigraphic distribution of Telemachus, however, these occurrences have not provided increased resolution of the paleobiology of the cone or a sufficient suite of characters that can be used to accurately define the taxon. The systematic affinities of Telemachus and the relationship of the fossil with both living and extinct families of conifers also remain unclear. The genus has been variously assigned to the extinct conifer families Voltziaceae (Retallack 1981; Yao et al. 1993) and Cycadocarpidiaceae (Anderson and Anderson 1983) on the basis of seed cone features. Telemachus

\footnotetext{
${ }^{1}$ Author for correspondence; e-mail: iescapa@mef.org.ar.
}

Manuscript received December 2009; revised manuscript received February 2010. has also been related to Podocarpaceae because of its frequent association with multiveined leaves that exhibit podocarpaceous features (see Axsmith et al. 1998). The presence of Telemachus in Triassic shales from Antarctica was first reported by Yao et al. (1993), on the basis of two specimens of the type species, Telemachus elongatus, collected on Mount Falla, from the Upper Triassic Falla Formation in the Central Transantarctic Mountains (CTM). Subsequently, more than 50 additional specimens were collected from two different localities: a site informally known as Alfie's Elbow, also in the CTM, and the Allan Hills, in southern Victoria Land. These new samples provide for a more complete description of $T$. elongatus and also contribute to the characterization of an additional species, distinguished by highly reduced bracts.

In addition to Telemachus, there is another conifer seed cone that has been reported from the Triassic of Antarctica. Parasciadopitys Yao, Taylor et Taylor (1997), from the Middle Triassic of Fremouw Peak, CTM, was described from permineralized specimens with multiovulate ovuliferous complexes (OCs) and was tentatively assigned to the Taxodiaceae (=Cupressaceae sensu lato). The relationship between Parasciadopitys and Telemachus was briefly discussed by Yao et al. (1997), on the basis of features observed in both seed cones, despite the fact that the specimens represented different preservational modes. Here we apply a modification of the classic transfer technique (Escapa et al. 2010) in order to understand the three-dimensional morphology and anatomy of Telemachus and to compare this cone with Parascia- 
dopitys. This study not only provides the opportunity to consider the relationship of the disparate morphospecies in reconstructing the parent plant of Telemachus but also makes it possible to consider the phylogenetic position of this Triassic conifer in the context of the transitional conifers.

\section{Material and Methods}

New compressed specimens were collected from two localities in the Triassic of Antarctica during several field seasons. One site occurs at the Alfie's Elbow locality in the Shackleton Glacier region, CTM (Taylor et al. 1996). This locality is stratigraphically placed in the upper part of the Fremouw Formation or the lower part of the Falla Formation. The precise stratigraphic position is not clear because of the isolated nature of the outcrop, and the age of the locality has been mentioned as late Middle to early Late Triassic (Farabee et al. 1989; Axsmith et al. 2000). The second locality occurs in the Allan Hills, southern Victoria Land, and is stratigraphically assigned to Member $\mathrm{C}$ of the Lashly Formation. This lithostratigraphic unit has been regarded as Middle-Late Triassic (Kyle 1977; Kyle and Schopf 1982). Member C, in particular, has been included in subzone $\mathrm{C}$ of the palynological zonation Alisporites (Kyle 1977), which is late Middle-early Late Triassic in age. On the basis of vertebrate fossils from Mount Dearborn, Hammer et al. (2004) suggest a Late Triassic (Carnian) age for Lashly Member C.

The megafloral content of both the Lashly Formation and the Falla Formation shows general similarity in composition, with a high percentage of corystosperms, including a high diversity of leaf morphotypes (Dicroidium spp.) and also the component pollen and seed-producing organs (Pteruchus, Umkomasia) of this group. Minor components of the flora include ferns, cycadophytes, ginkgophytes, conifer foliage and cones, and other poorly preserved possible seed plants.

\section{Fossil Preparation}

Numerous seed cones of Telemachus were examined and include those preserved in various planes of section, ranging from radial longitudinal to nearly transverse section. Some specimens can be related to Telemachus elongatus, while others are separated from the type species and here described as Telemachus antarcticus Escapa, Decombeix, Taylor \& Taylor sp. nov. There are a few additional specimens in which the preservation does not permit assignment with either of these two forms, i.e., specimens T218, T356, T389, T646, T1189, and T1223. Throughout the study, a number of physical and chemical techniques were utilized in order to obtain the maximum amount of information from the specimens. For instance, the modified transfer technique (Escapa et al. 2010) was used to describe the three-dimensional structures and anatomical details, using acetate peels mounted on standard microscope slides with Eukitt as a mounting medium. The classic transfer technique (Walton 1923,1928 ) was also employed to observe external char- acters of the cones. Using this technique, we embedded the specimens in Bio-Plastic, and the shale was chemically macerated using $48 \%$ hydrofluoric acid until the rock was digested (Escapa et al. 2010).

Cuticles of the bracts and scale complexes are highly coalified, and thus it was impossible to obtain any information on the epidermal cell patterns or cuticular anatomy, even using fluorescence microscopy and chemical bleaching. The phyllotaxy of the cones was determined using the method of contact parastichies (Watson et al. 1987). All specimens, including peels and slides, are housed in the paleobotany division of the Natural History Museum and Biodiversity Institute, University of Kansas, Lawrence, under acquisition numbers that are indicated in the diagnosis and plate explanations.

\section{Cladistic Analysis}

The phylogenetic position of Telemachus was evaluated using the morphological matrix of Rothwell et al. (2005) for transitional conifers. Three additional taxa were incorporated into the original matrix. These conifers are theoretical representations (=composite taxa), based on the association of seed cone and leaf morphospecies that were consistently found at the same site (see scoring of the composite taxa in the appendix in the online edition of the International Journal of Plant Sciences). In this context, the species T. elongatus (seed cone) and Heidiphyllum elongatum (leaf) were included as a single terminal, as well as Swedenborgia cryptomerioides (seed cone) and Podozamites schenkii (leaf; see Harris 1937) and Parasciadopitys aequata (seed cone) and Notophytum krauselii (axes and leaves). The association between the first pair of species (T. elongatus and H. elongatum) was recorded from several localities and is widely accepted (see Axsmith et al. 1998 and citations therein). A similar association was noted by Miller (1977), who suggested that $S$. cryptomerioides-P. schenkii represented parts of the same plant, on the basis of their frequent association. Finally, the relationship between the Antarctic taxa Parasciadopitys and Notophytum was suggested by Axsmith et al. (1998).

The modified matrix used here includes 24 taxa and 57 morphological characters, all of which were treated as unordered. The average number of missing entries for the matrix is $20 \%$. Maximum parsimony analysis using the program TNT (Goloboff et al. 2008) was performed, entailing a heuristic search based on 10,000 random additional sequences plus tree bisection and reconnection, saving 10 trees per replication. All characters were equally weighted, and the resulting phylogenetic trees were rooted using Callistophyton poroxyloides.

\section{Nomenclature}

Anderson (1978) included both the generic and species characters of T. elongatus in a single diagnosis. Since several species have been described, we propose here a generic diagnosis for Telemachus and an emended diagnosis for the type species Telemachus elongatum. 


\section{Systematics}

$$
\begin{gathered}
\text { Division-Coniferophyta } \\
\text { Class_Coniferopsida } \\
\text { Order_Voltziales } \\
\text { Family_indet. }
\end{gathered}
$$

Telemachus Anderson emend. Yao,

Taylor et Taylor, 1993

Diagnosis (emended). Seed cone with OCs helically arranged on a thick woody axis; each OC composed of a bract and ovuliferous scale fused for about half their length; bract simple. Ovuliferous scale apex divided into five lobes; vascular system of bract and scale fused at base of the OC, resulting in one vascular trace in the bract and five in the scale; two to five ovules per OC.

Type species. Telemachus elongatus Anderson emend. Yao, Taylor et Taylor, 1993.

\section{Telemachus elongatus Anderson emend. Yao, Taylor et Taylor, 1993 (Figs. 1-3, 6A)}

Diagnosis (emended). Ovate seed cone, $4.0-6.0 \mathrm{~cm}$ long and $4.0-6.0 \mathrm{~cm}$ wide, with helically arranged cone scales attached to axis, up to $4 \mathrm{~mm}$ wide. Cone scale up to $3.0 \mathrm{~cm}$ long; bract and ovuliferous scale fused for about half their length; bract elongate, extending beyond length of ovuliferous scale; scale five lobed at apex and bearing two or three slightly reflexed ovules below scale lobes. Bract and scale composed of parenchymatous ground tissue; vascular system with occasional sclereids; sclereid walls $\sim 40 \mu \mathrm{m}$ thick; tracheids with scalariform thickenings. Ovules $1.5-2.0 \mathrm{~mm}$ in diameter, with integument $40-60 \mu \mathrm{m}$ thick and nucellus attached only at its base. Cuticle from basal part of cone scale thin $(1 \mu \mathrm{m})$, with longitudinally elongate cells arranged in radial files; occasional monocyclic stomata, with thick cuticles and sunken guard cells surrounded by five or six subsidiary cells; cuticle from cone-scale distal region thin, showing elongate hexagonal cells (75.0-106.0 $\mu \mathrm{m} \times 7.2-9.6 \mu \mathrm{m})$; other epidermal cells irregular in outline; cuticle from outer integument of ovule thick, composed of rectangular-polygonal cells with strongly cutinized anticlinal walls, forming short, spinelike projections or flanges at cell corners; cuticle of inner integument lacking projections and less cutinized; nucellar cuticle showing hexagonal cell outline (15.0-18.7 $\mu \mathrm{m})$, with straight anticlinal walls and granular surface.

Specimens. Mount Falla: T7-166, T-5742. Allan Hills: T-202, T8-218, T8-220, T11-343, T11-361, T11-363, T11-386, T11-389, T11-390, T11-393, T11-414. Alfie's Elbow: T12-992, T12-1065, T-1302, T-1303, T-1440, T-1517, T-5641, T-5642, T-5580, T-5608, T-5617, T-5594.

Description: morphology. The seed cones are avote and range from 46 to $55 \mathrm{~mm}$ long (fig. $1 A-1 C$ ); up to $40 \mathrm{~mm}$ wide, including the bracts (probably incomplete); and 20-22 $\mathrm{mm}$ wide without the bracts. Each cone consists of a woody central axis with helically arranged OCs (the fused scale and bract, also termed bract-scale complex). The axis is broad $(\leq 5$ $\mathrm{mm}$ wide) and the surface irregular as a result of the insertion points of the OCs (fig. 1A). OCs diverge from the cone axis at $\sim 90^{\circ}$ in the central region of the cone, at more acute angles apically, and in a more downward direction toward the base of the cone (figs. $1 A, 1 D, 2 C$ ).

The OC is composed of a proximal stalk up to $6 \mathrm{~mm}$ long by $2 \mathrm{~mm}$ wide in the central region and a distal head that is slightly flared to $\sim 7 \mathrm{~mm}$ in width. The stalk is straight, woody (figs. $1 D, 2 A, 2 D)$, and longitudinally striated with $>10$ conspicuous ribs (fig. 2A). The distal head is divided for almost half its length into five distinct segments, each of which represents a free tip of the ovuliferous scale (fig. $2 B, 2 E$ ). The lobes of the scale possess a thick proximal region but are more elongate at the distal end, with an acute apex (fig. 2B). Successive tangential sections indicate that the bract is free from the ovuliferous scale for almost the entire length of the distal head, while at the level of the OC stalk, the bract and scale are fused (figs. $2 D$, $3 A)$. The free part of the bract is $1.5-2.7 \mathrm{~mm}$ wide at the base and at least $15 \mathrm{~mm}$ long (figs. $1 E, 1 F, 2 C, 2 D$ ); there are several specimens where this structure appears to be broken, suggesting that at some stage in the development of the cone, the bracts may have been more extensive. Multiple specimens of varying lengths suggest that the surface of the bract is smooth, with entire margins (fig. $1 E, 1 F$ ). Bracts contain a single, median terete vein. Bracts in T. elongatus are variously oriented, depending on the stage of OC development. They are reflexed downward toward the base of the cone at angles of up to $140^{\circ}$ in mature cones (fig. $1 B, 1 D$ ), while in immature cones they arise from the cone axis at right angles (fig. $1 A$ ).

In T. elongatus, ovules are attached to the adaxial surface of the ovuliferous scale (figs. $2 D, 3 A$ ). Sections of the specimens from Antarctica suggest that the number of ovules may be five per scale; however, we have been unable to consistently demonstrate this number in all samples. For instance, in some cases there are two or three ovules that can be easily recognized on the basis of serial sections, but in other instances the position of the ovules on the scales is occupied by a small structure that may represent either an aborted ovule or another morphological feature of the scale lobe.

Anatomy. In most of the sectioned specimens, the axis of the cone is present, but often the tissues are not well preserved. On the other hand, some OCs are sufficiently well preserved that it is possible to distinguish cellular details (fig. 3). In these specimens, the epidermis is represented by an opaque layer in which individual cells cannot be distinguished. Both the bract and the scale are composed of a parenchymatous ground tissue and conducting elements of the vascular system (fig. 3A-3C). Parenchymatous cells are $15-40 \mu \mathrm{m}$ wide, and some have opaque contents (fig. $3 C, 3 E$ ). There is some suggestion that larger thin-walled cells were present in the outer part of the scale and bract, but the walls of the cells are not always easy to delimit (fig. $3 A$ ).

The ovuliferous scale in T. elongatus contains a single terete strand of vascular tissue that divides and extends into each of the scale lobes (figs. $2 E, 3 A, 3 E$ ). In the bract there is also a single vascular bundle that extends undivided from the base into the tip (fig. $3 \mathrm{C}$ ). The scale and bract bundles are fused into a single strand at the level of the OC stalk. Tracheids range from 15 to $33 \mu \mathrm{m}$ in diameter and have scalariform secondary wall thickenings (fig. $3 B$ ). In a few sections, there are thicker-walled cells near the vascular strands of the scale and bract that are terete in transverse section and interpreted as 

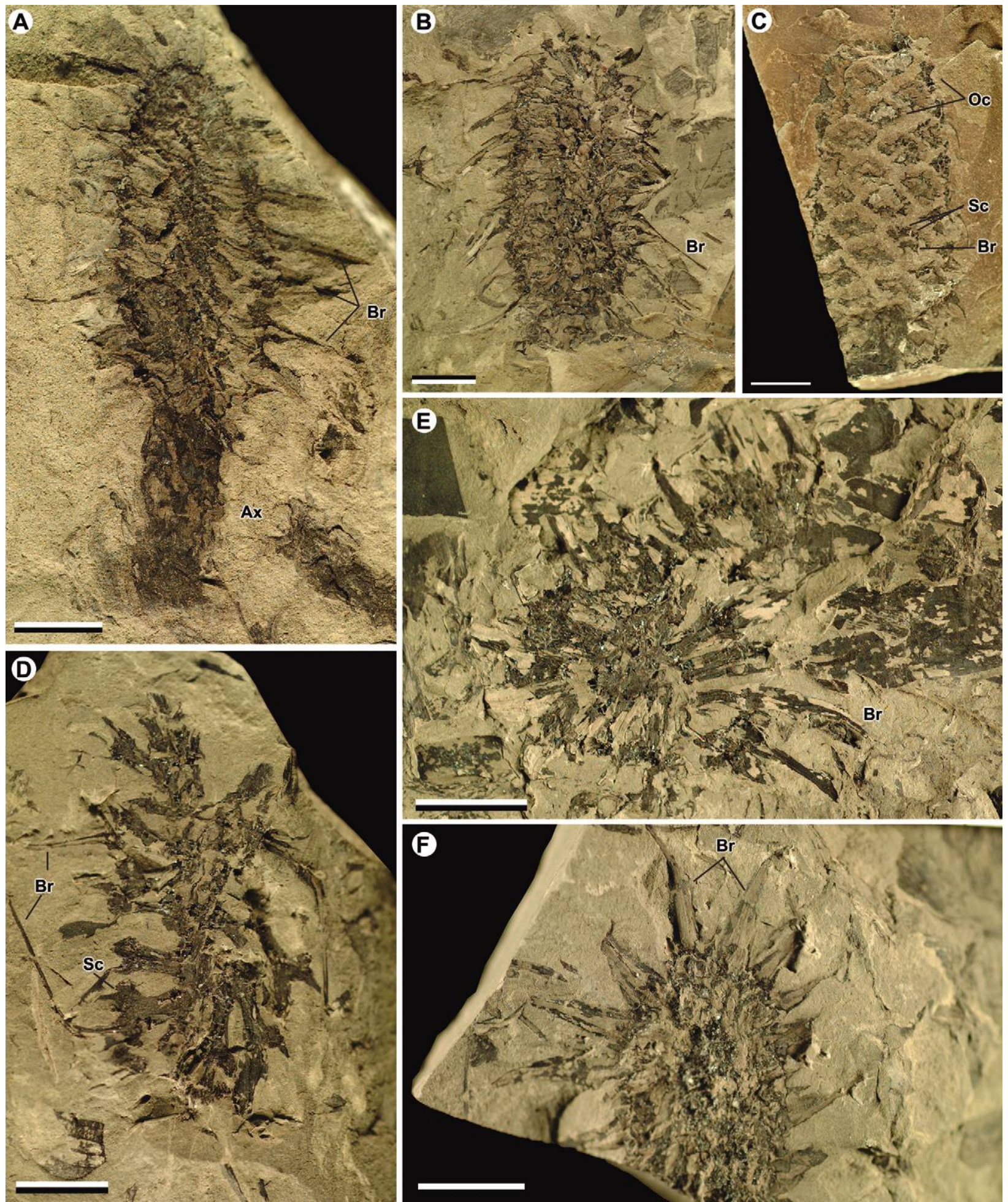

Fig. 1 Seed cones of Telemachus elongatus from Allan Hills and Alfie's Elbow, Antarctica. A, Young seed cone organically attached to axis, showing the well-developed bracts. T8-220. Scale bar $=10 \mathrm{~mm} . B$, Mature seed cone compressed longitudinally, showing ovuliferous complexes and long reflexed bracts in side view. T11-414. Scale bar $=10 \mathrm{~mm}$. C, Seed cone, showing the ovuliferous complexes in front view. T-1302. Scale bar $=10 \mathrm{~mm} . D$, Seed cone in longitudinal section, showing ovuliferous complexes with bracts and scale lobes. T11-361. Scale bar $=10 \mathrm{~mm} . E$, Seed cone compressed vertically, showing ovuliferous complexes with long bracts in cross section. T11-343. Scale bar $=10 \mathrm{~mm}$. $F$, Seed cone compressed obliquely, showing the adaxial surfaces of the ovuliferous complexes and the abaxial bracts. T11-363. Scale $=10 \mathrm{~mm}$. Ax = axis; $\mathrm{Br}=$ bract; $\mathrm{O} c=$ ovuliferous complex; $S c=$ scale. 

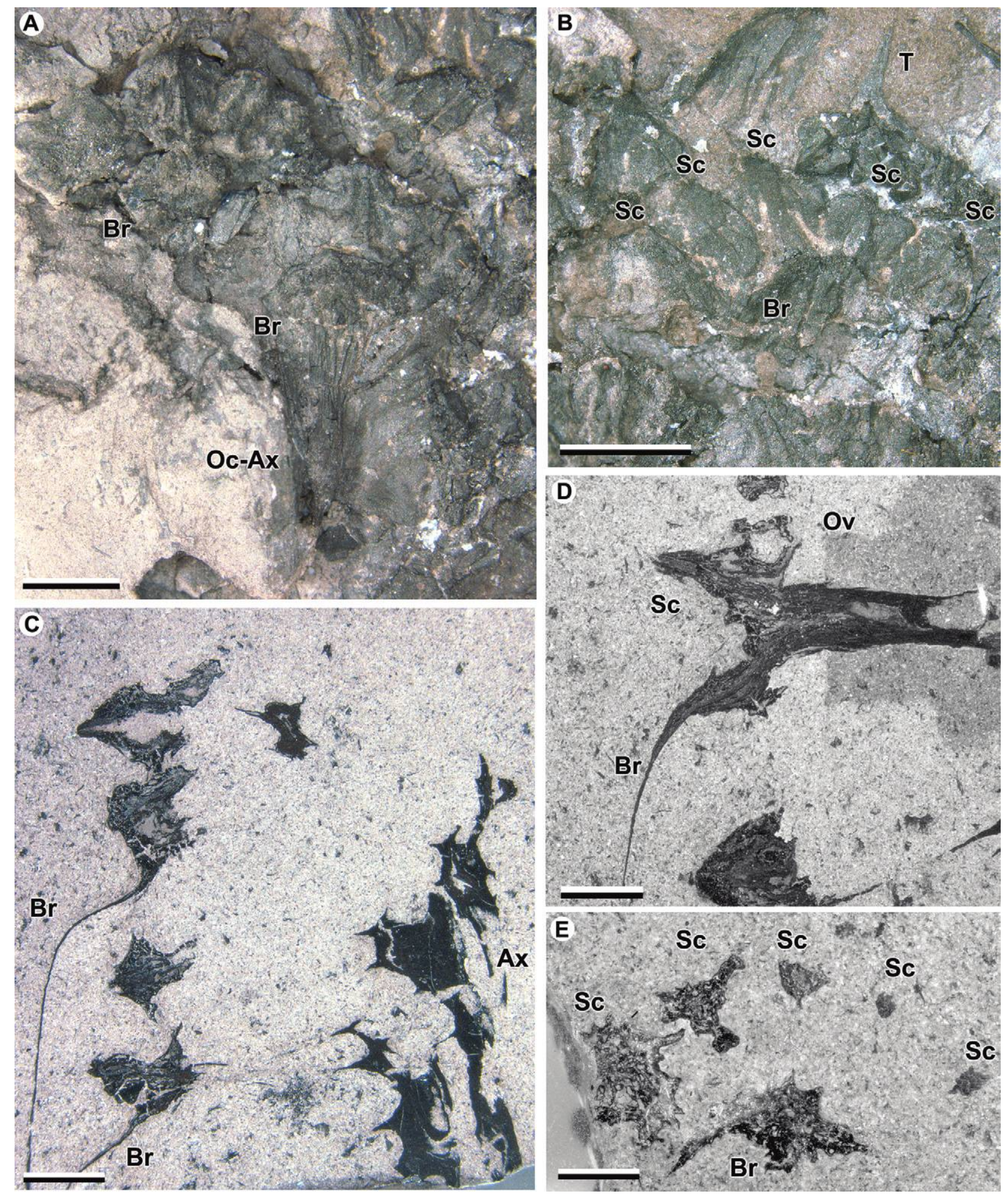

Fig. 2 Seed cones of Telemachus elongatus. A, Two ovuliferous complexes in abaxial view, showing broken bracts and scale lobes directly above them. Transfer preparation T-5641. Scale bar $=2 \mathrm{~mm} . B$, Detail of distal head of the ovuliferous complex, showing five scale lobes and a scale lobe tip. Transfer preparation T-5641. Scale bar $=2 \mathrm{~mm}$. C, Longitudinal view of part of a cone, showing the cone axis (right) and the outer edge of several ovuliferous complexes. Note the long bract tips. T-5594. Scale bar $=2 \mathrm{~mm}$. $D$, Ovuliferous complex in longitudinal section (side view), showing the scale, bract, and position of a single ovule. T-5594. Scale bar $=2 \mathrm{~mm}$. E, Ovuliferous complex in cross section (tangential section of cone), showing the five tips of the scale lobes and the subtending bract. At this level, every scale lobe and bract each has a single vascular strand. T-5594. Scale bar $=1 \mathrm{~mm}$. $A x=$ cone axis; $B r=$ bract; $O c-A x=$ ovuliferous complex axis; $O v=$ ovule; $S c=$ scale; $T=$ scale lobe tip. 

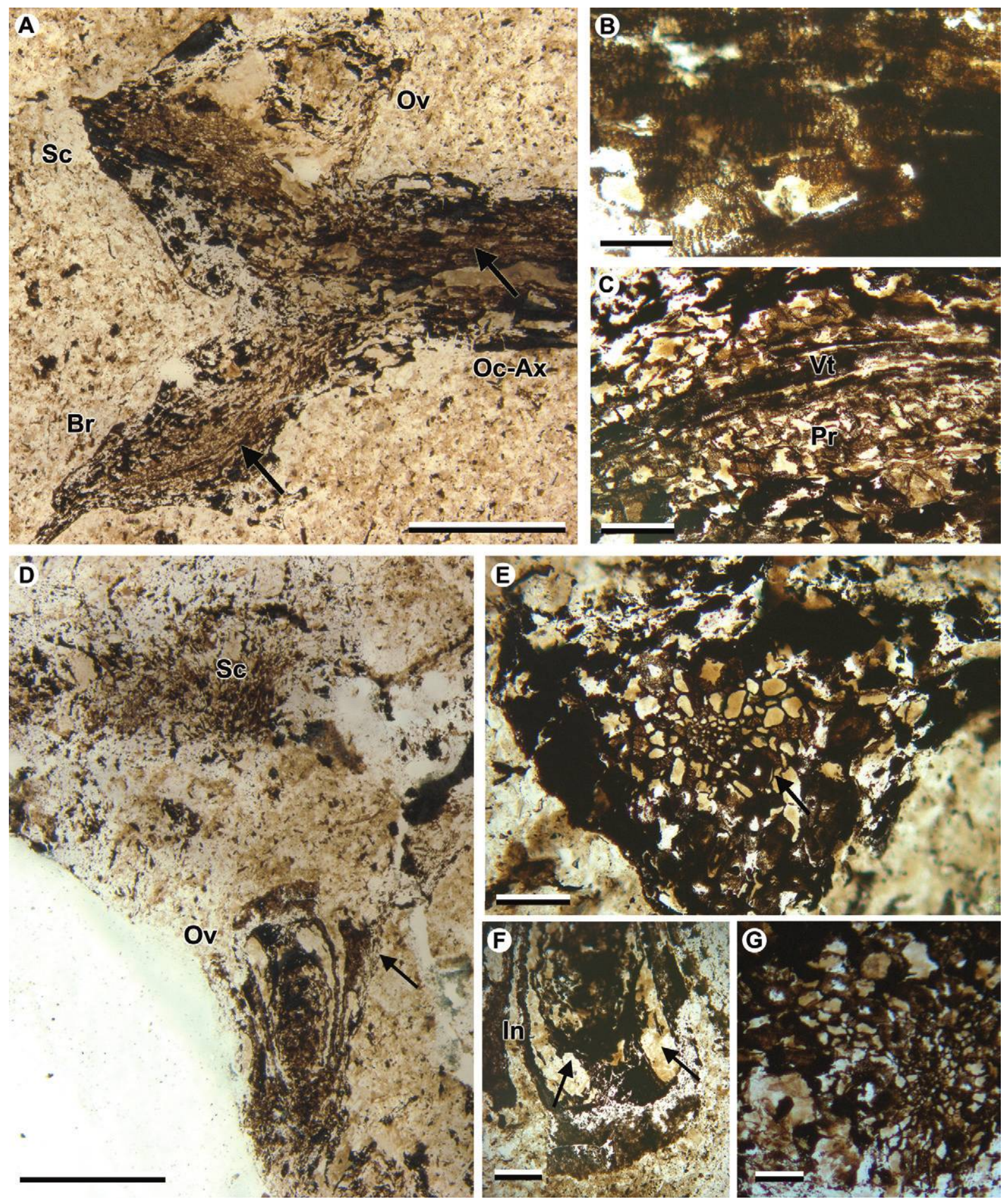

Fig. 3 Anatomical details of Telemachus elongatus from transfer preparations. A, Distal head of ovuliferous complex in longitudinal section (side view), showing the anatomy. Arrows indicate vascular strand in the ovuliferous complex stalk and in the bract. T-5594. Scale bar $=2 \mathrm{~mm}$. $B$, Detail of scale vascular tissue in $A$; note scalariform secondary wall thickenings on the tracheids. T-5594. Scale bar $=50 \mu \mathrm{m}$. C, Detail of the bract in $A$, showing large parenchymatous cells, smaller parenchymatous cells, and vascular tissue in the center. T-5594. Scale bar $=100 \mu \mathrm{m}$. $D$, Seed cone in cross section. Note the ovule and the integument of a second ovule (arrow) and ovuliferous scale tissue. Cone axis would be at the bottom. T-5594. Scale bar $=1 \mathrm{~mm}$. E, Cross section of the vascular strand in the tip of a scale lobe. Note the thick-walled cells (arrow) associated with the vascular tissue. T-5594. Scale bar $=100 \mu \mathrm{m}$. F, Higher magnification of the base of the ovule in $D$, showing the integument and attachment of the nucellus at the base (arrow). T-5594. Scale bar $=200 \mu \mathrm{m}$. G. Cross section of the tip of a scale lobe in a more proximal region than $E$, showing larger vascular strand. T-5594. Scale bar $=100 \mu \mathrm{m}$. Br = bract; $I n=$ integument; Oc-Ax= ovuliferous complex axis; $\mathrm{O} v=\mathrm{ovule} ; \mathrm{Pr}=$ parenchyma; $S c=$ scale. 
sclereids (fig. 3E). Ovules are well preserved on some of the specimens (fig. $3 D, 3 F$ ). They are oval in longitudinal section, $\sim 1.3 \mathrm{~mm}$ long and $0.3 \mathrm{~mm}$ wide (fig. $3 D, 3 F$ ). The preserved part of the integument is $40-60 \mu \mathrm{m}$ thick, and the nucellus is attached only at the chalazal end (fig. $3 F$ ).

\section{Telemachus antarcticus Escapa, Decombeix, Taylor \& Taylor sp. nov. (Figs. 4, 5, 6B)}

Diagnosis. Ovate seed cone, up to $40 \mathrm{~mm}$ long and 15-18 $\mathrm{mm}$ wide, with helically arranged cone scales attached to axis; OCs $4 \mathrm{~mm}$ long, with bract and scale fused for about twothirds of length; bract up to $3 \mathrm{~mm}$ long, with smooth margin; scale five lobed at apex and bearing up to five ovules.

Specimens. Allan Hills: T-204, T-220, T-354, T-355, T11-390, T-391, T11-409, T11-411.

Holotype. Allan Hills T11-411.

Type locality. Allan Hills, southern Victoria Land, Antarctica.

Stratigraphy. Member C, Lashly Formation.

Age. Late Triassic.

Description. Some cones in the collection are terminally attached to branches $\sim 4.0 \mathrm{~mm}$ wide (fig. $4 A, 4 D$ ). Along the branches are irregular striations that may represent the position of leaf scars (fig. $4 A$ ). The cones are oblong in outline, up to $40 \mathrm{~mm}$ long and $15-18 \mathrm{~mm}$ wide; the apex is rounded and the base slightly truncated (fig. 4A-4D).

One of the interesting features of this cone type is the fact that almost one-third of the total diameter of the cone is represented by the axis (fig. 4B). Along the cone axis are rounded scars that represent the points of insertion of the OCs (fig. $4 A$ ). These scars result in an irregular ornamentation pattern on the axis. In the cones of $T$. antarcticus, we estimate that the number of bract-scale complexes per cone axis range from 100 to 120 and that these complexes are equally spaced in a helical arrangement (parastichy number $10+13$ ). Each bract-scale complex diverges from the axis at right angles in the midsection of each cone and at more acute angles toward the apex; basally, the ovuliferous bract-scale complexes are more reflexed and directed downward (fig. 4A, 4D). Each complex is robust and consists of a basal stalk, an expanded head interpreted as the fusion of bract and ovuliferous scale, and distal projections or lobes (fig. 4G). The dimensions of the bract-scale complexes vary, depending on their position, with the longest located in the midsection of the cone (3.5-4 $\mathrm{mm}$ long $\times 2-4 \mathrm{~mm}$ wide) and decreasing slightly toward the apex and base. In lateral view, the OCs are $0.9-1.3 \mathrm{~mm}$ thick in the midregion of the stalk and 3.5-4.5 mm thick at the level of the expanded head. The stalk shows several longitudinal ribs, as well as delicate striations that may represent the pattern of epidermal cells (fig. 4G). The expanded head of the bract-scale complex is subdivided on the adaxial surface into five scale lobes (fig. 4G). When viewed on the adaxial surface, each lobe is triangular in outline, with an entire margin and an acute apex (fig. 4G). Each scale lobe is straight or slightly reflexed and up to $1.5-2.0 \mathrm{~mm}$ long and $0.5-0.8 \mathrm{~mm}$ wide at the base. In some longitudinal sections, it is possible to view two elongated triangular lobes in the bract-scale complexes (fig. 4F). These could represent two scale lobes or a single lobe and a short abaxial bract. In this cone type, the bracts are short, up to $3 \mathrm{~mm}$ long; have a smooth margin; and are only slightly reflexed (fig. 4D). Transverse sections of the OCs obtained using the modified transfer technique show features of the internal structure of this cone type (fig. 5). Distal sections of the OCs indicate that the apical portion of the scale lobes and the bract are not fused (fig. $5 A-5 C$ ). The free distal portion of the bract consists of a robust central component and two small lateral wings. In the midregion of the OC, the scale lobes are fused into a single flattened structure that is abaxially reflexed. More proximally, this structure is fused with the bract to form the bract-scale complex stalk (fig. 5D). On the adaxial side of the stalk, close to where the bract and scale lobes are fused, there are four or five rounded structures that may represent ovules (fig. $5 D$ ). These structures range from 1.0 to $1.8 \mathrm{~mm}$ in diameter and are compactly arranged.

\section{Comparisons with Other Species of Telemachus}

The species described here are assigned to the conifer genus Telemachus Anderson on the basis of the presence of lignified OCs, partial fusion of the bract and scale, and five-lobed ovuliferous scale. The principal morphological differences between the species described here correspond to the size of the cones and OCs and the length of the bracts (table 1). To date, there are seven species of Telemachus, differing in the morphology and size of the bracts. Six of the seven species were originally reported from South Africa (Anderson 1978; Anderson and Anderson 2003), and most of them were just briefly described. The validity of these species should be reanalyzed on the basis of detailed descriptions since some may represent different views or different developmental stages of the same form. For example, the principal differences cited between $T$. elongatus and Telemachus grandis are the size of the cones and the length of bracts (Anderson and Anderson 2003). However, the occurrence of cones of different sizes in a single species is common in extant and fossil conifers, and the length of bracts in fossils is not always clear since there is often just a segment of this structure preserved.

A logical question when two or more species of the same genus co-occur at the same locality concerns whether these socalled species represent different developmental stages of the same taxon. If this hypothesis is considered for the Antarctic cones, the long bracts present in T. elongatus might be interpreted as broken off or flattened against the surface in the cones of $T$. antarcticus and therefore might represent perhaps a more mature stage in cone development. However, T. elongatus is represented in our sample by both mature and immature cones, indicating that the bracts remained attached even in advanced ontogenetic stages. Additionally, the mature specimens of $T$. elongatus are larger than those of T. antarcticus. On the other hand, T. antarcticus could represent an early ontogenetic stage of Telemachus elongatum in which the bract had not reached its final size; however, small specimens of T. elongatum suggest that the bract is already developed in young cones of this type. The totality of this evidence supports the presence of two different species of Telemachus in the Triassic of Antarctica. In this context, we propose a new species, T. antarcticus; in general features, the new species is similar to Telemachus dubibractus from the Triassic of South Africa. However, the latter was poorly defined on the basis of a single specimen (Anderson and 

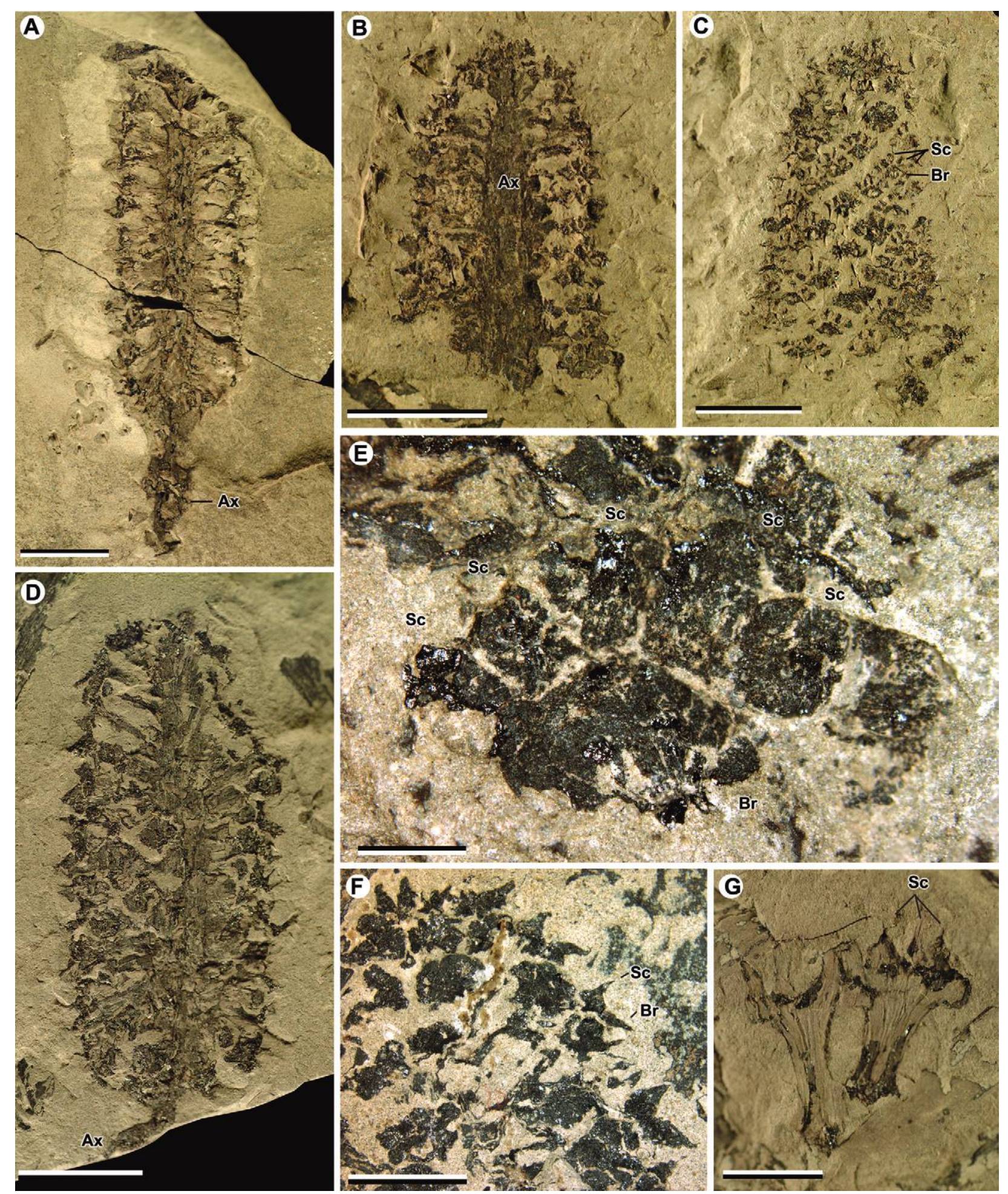

Fig. 4 Seed cones of Telemachus antarcticus from Allan Hills, Antarctica. A, Seed cone in longitudinal section, showing the central axis and the ovuliferous complexes. T11-355. Scale bar $=10 \mathrm{~mm}$. B, Distal region of seed cone compressed longitudinally, showing the broad central axis and the ovuliferous complexes. T11-409. Scale bar $=10 \mathrm{~mm}$. C, Distal region of seed cone, showing the external view of the ovuliferous complexes. Note the adaxial position of the scale lobes and the abaxial position of the bract. T11-409. Scale bar $=10 \mathrm{~mm}$. D, Seed cone in longitudinal section, showing the central axis and the ovuliferous complexes in lateral view. Note the presence of short bracts. T11-411. Scale bar $=10 \mathrm{~mm}$. E, Cross section of an ovuliferous complex (tangential to cone axis). The five scale lobes are adaxially disposed with respect to the bract. T11-409. Scale bar $=$ $1 \mathrm{~mm}$. F, Distal part of seed cone, showing the bracts and scale lobe tips. T11-391. Scale bar $=5 \mathrm{~mm}$. G, Detail of two isolated ovuliferous complexes in adaxial view. Note the tips of the scale lobes. T11-389. Scale bar $=5 \mathrm{~mm}$. $A x=$ cone axis; $B r=$ bract; $S c=$ scale. 

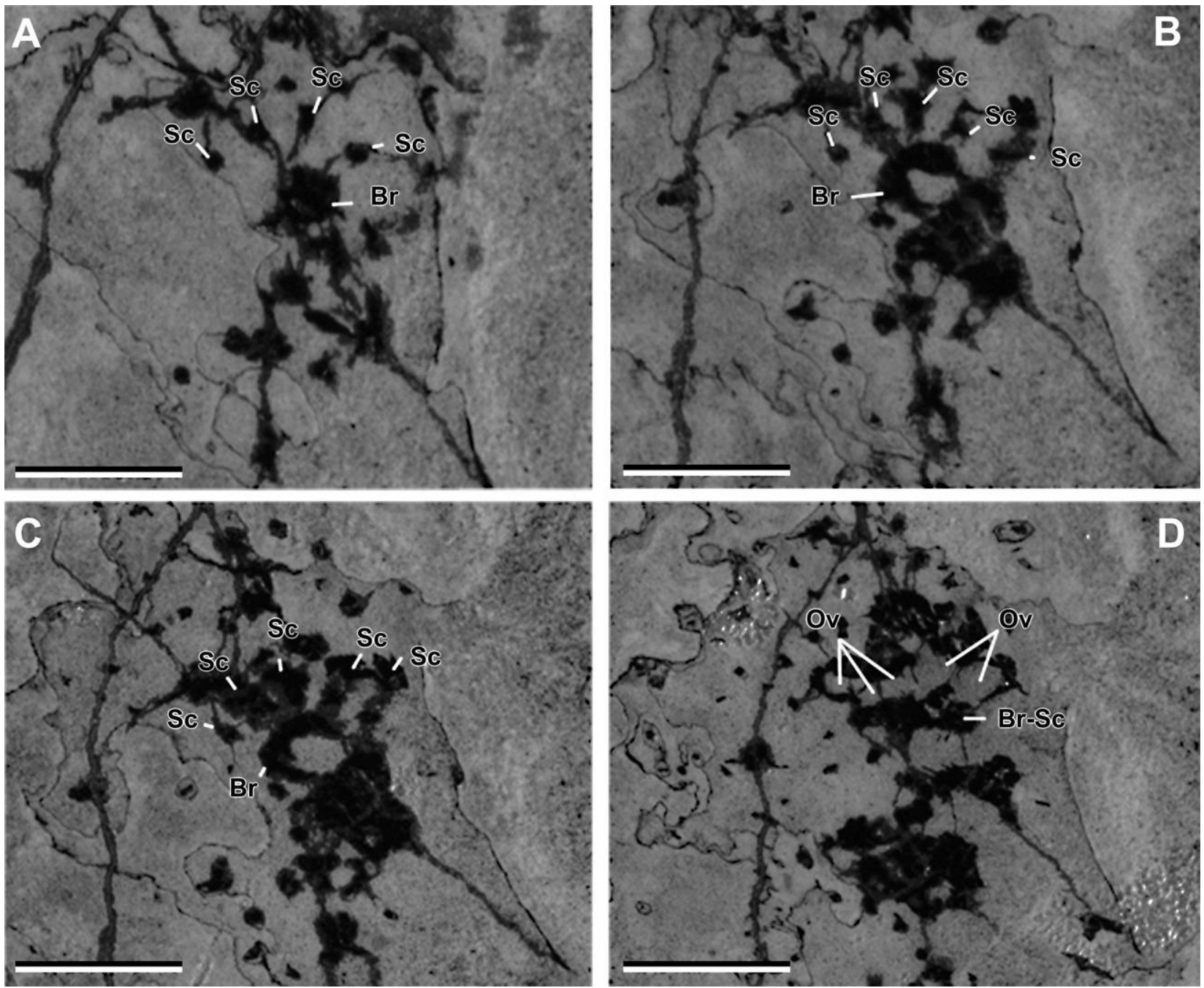

Fig. 5 Serial sections of Telemachus antarcticus seed cone, showing progressive fusion of the scale and bract from the exterior toward the cone axis $(A-D)$ and the possible position of the ovules $(D)$. Transfer preparations of T11-391. Scale bar $=5 \mathrm{~mm} . B r=$ bract; $B r-S c=$ bract and scale fused; $\mathrm{O} v$ = ovule; $\mathrm{Sc}=$ scale.

Anderson 2003), and the diagnosis does not include several characters needed in order to compare these two taxa unambiguously. The two species of Telemachus from the Triassic of Antarctica are associated with only a single foliage morphospecies, Heidiphyllum elongatum. Leaves of conifers commonly present a high degree of homoplasy, however, and morphologically identical leaves are often founded associated with more than one natural species. Additional studies of H. elongatum leaves from different Antarctic localities are needed to determine whether there are differences in cuticular and morphological characters that might be used to separate these leaves. It is interesting to note that differences in stomatal orientation of $H$. elongatum from Antarctica and South Africa have been mentioned (Axsmith et al. 2000).

The co-occurrence of more than one species of Telemachus was also reported from the Triassic Cacheuta Formation in Mendoza Province, Argentina (Morel 1994), where T. elongatus and Telemachus lignosus occur at the same locality. As in Antarctica, these two Telemachus species are found in association with the single leaf type, H. elongatum (Morel 1994).

\section{Discussion}

Telemachus and Parasciadopitys, Two Forms of the Same Taxon?

Two conifer seed cones have been recorded thus far from Triassic rocks of Antarctica: compressed Telemachus and permineralized Parasciadopitys (Yao et al. 1997). The former was initially described on the basis of isolated seed cones repeatedly found in association with Podozamites/Heidiphyllum leaves (Yao et al. 1993). The assignment of Telemachus to the conifers was supported by general features such as its large size, helical arrangement of the cone units, and lobed distal scales. Yao et al. (1997) defined the monotypic genus Parasciadopitys on the basis of two specimens of silicified cones from the Middle Triassic of Fremouw Peak, CTM, Antarctica. 


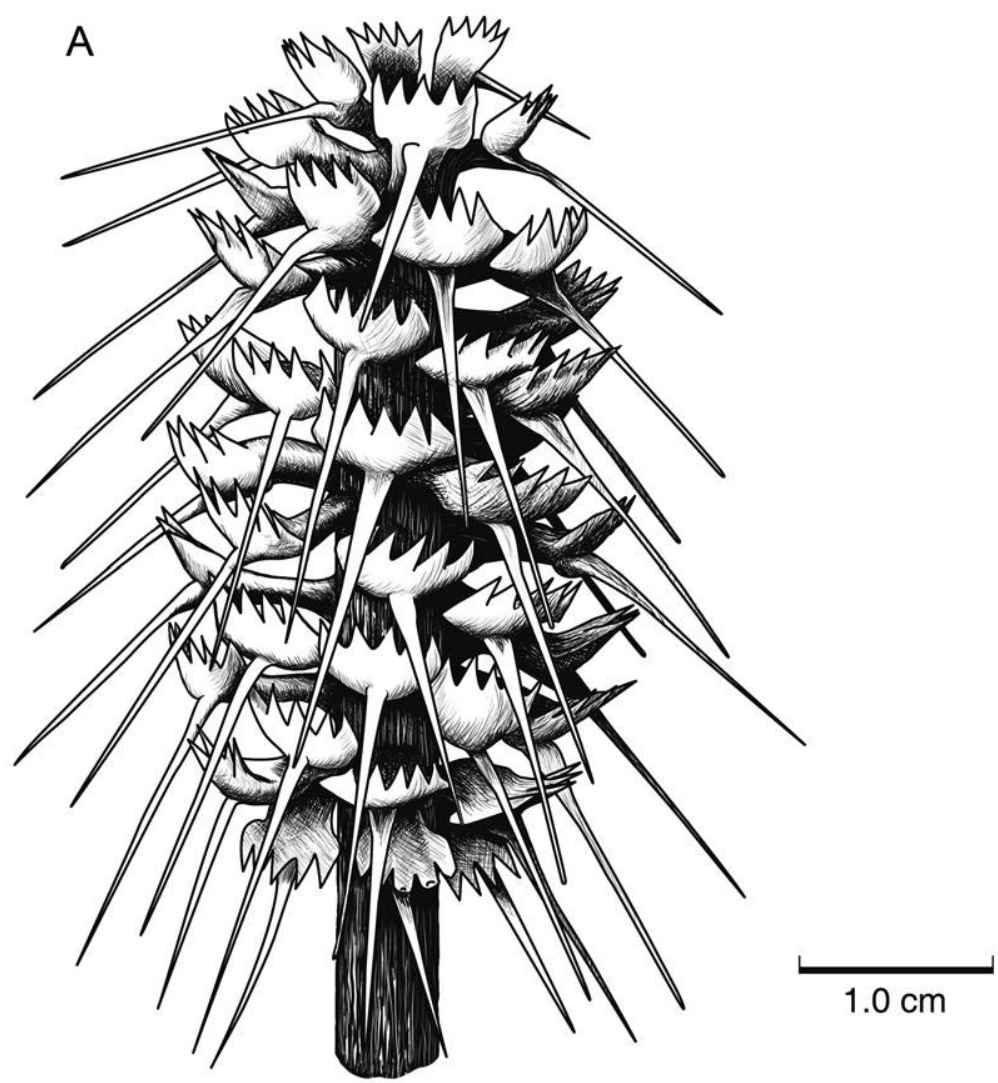

B

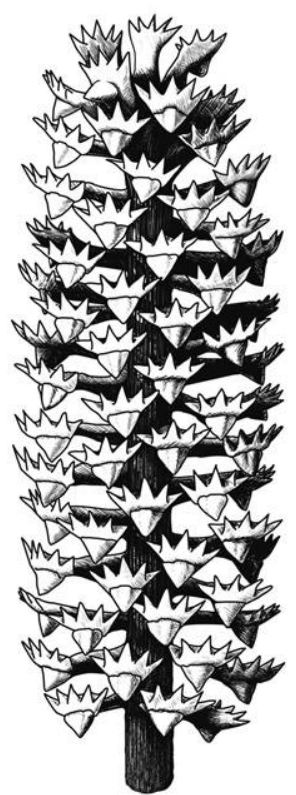

Fig. 6 Hypothetical reconstructions of Telemachus elongatus $(A)$ and Telemachus antarcticus $(B)$ ovulate cones.

The genus was originally included in the family Taxodiaceae (=Cupressaceae sensu lato) on the basis of anatomical and morphological features of the OCs (see also Schulz and Stützel 2007). Many of these traits (e.g., morphology and anatomy of the ovules and bract-scale complexes, number of ovules, anatomy of the OC, and vascular trace anatomy) have an ambiguous value in the general context of conifer systematics, and the phylogenetic position of Parasciadopitys remains unresolved.
Several morphological similarities suggest a relationship between Telemachus and Parasciadopitys, including the woody OCs; partial fusion of bract and scale; entire bract; and number, morphology, and disposition of scale lobes. The new data on the anatomy of Telemachus presented here provide additional evidence that the two taxa are closely related. Important anatomical similarities include the presence of parenchymatous tissues that form most of the scale and bract;

Table 1

Comparisons of Telemachus Species from Different Triassic Localities

\begin{tabular}{|c|c|c|c|c|}
\hline Species & Cone length $(\mathrm{mm})$ & Bract length $(\mathrm{mm})$ & Bract margins & Occurrence \\
\hline Telemachus elongatus & 50 & Up to 23 & $\begin{array}{l}\text { Without proximal shoulders, } \\
\text { finely dentated }\end{array}$ & $\begin{array}{l}\text { South Africa, Antarctica, } \\
\text { Argentina }\end{array}$ \\
\hline Telemachus lignosus & Up to 60 & Up to 7 & $\begin{array}{l}\text { Without proximal shoulders } \\
\text { or dentation }\end{array}$ & New Zealand, Argentina \\
\hline Telemachus grandis & 70 & $\sim 13$ & $\begin{array}{l}\text { Without proximal shoulders } \\
\text { or dentation }\end{array}$ & South Africa \\
\hline Telemachus serribractus & 50 & $\sim 17$ & $\begin{array}{l}\text { Proximal shoulders and marked } \\
\text { dentation }\end{array}$ & South Africa \\
\hline Telemachus brachybractus & $25-35$ & $\sim 7$ & $\begin{array}{l}\text { Proximal shoulders and marked } \\
\text { dentation }\end{array}$ & South Africa \\
\hline Telemachus dubibractus & $50(?)$ & $\sim 4$ & $\begin{array}{l}\text { Without proximal shoulders or } \\
\text { dentation }\end{array}$ & South Africa \\
\hline Telemachus acutisquamus & Unknown & $\sim 9$ & Uncertain & South Africa \\
\hline Telemachus antarcticus & Up to 40 & Up to 3 & $\begin{array}{l}\text { Without proximal shoulders or } \\
\text { dentation }\end{array}$ & Antarctica \\
\hline
\end{tabular}


organization of the vascular system in the scale, bract, and stalk; and the presence of thick-walled cells associated with the vascular strands, all characters also observed in Parasciadopitys (Yao et al. 1997). The two genera have been distinguished from each other by two principal features: (1) the lack of a long bract and (2) the larger number of ovules per OC in Parasciadopitys (Yao et al. 1997). However, it now appears that these differences are negligible. First, on the basis of specimens from South Africa (Anderson and Anderson 2003) and information included in this study, it is clear that length and morphology of the bract are highly variable within Telemachus and thus may not be viable generic characters. Second, a review of the literature shows that the number and morphology of Telemachus ovules remain questionable. No ovules or evidence of the presence of ovules (i.e., vascular scars, seed cushions, etc.) was described in the original diagnosis (Anderson 1978). Retallack (1981) offered a generic diagnosis and described a new species from the Middle Triassic of New Zealand, Telemachus lignosus, including data on number and morphology of the ovules. Although the ovules are figured in line drawings (Retallack 1981, fig. 5), photographs of the actual specimens do not provide convincing evidence of ovule presence, and thus the description regarding their organization and morphology remains equivocal. Retallack (1981) noted that the fossils consisted of poorly preserved impressions and described the ovules only as ovoid.

Yao et al. (1993) described two specimens of compressed seed cones assigned to Telemachus elongatus from the Late Triassic Falla Formation of Antarctica; one of them showed two possible ovules on an OC. Maceration of this specimen provided details about three different types of cuticles and showed bisaccate pollen grains intercalated between the suggested ovule and nucellar cuticles (Yao et al. 1997). However, the cone from which the ovules were obtained was mature and the ovules disassociated, suggesting that the ovules described by Yao et al. (1993) could represent contaminants. Morel (1994) and Lutz (2006) briefly mentioned the presence of ovules in Telemachus cones from two different Triassic basins in Argentina and indicated that there were from two to four ovules per cone scale.

In the specimens described in this article, we have no definitive evidence for the presence of ovules based on the external morphology of the cones. The thin sections and peels of $T$. elongatus and Telemachus antarcticus, however, suggest the presence of four or five ovules and represent the best evidence of ovules in Telemachus cones to date. The disposition, arrangement, and anatomy of the ovules show numerous similarities to the ovules in Parasciadopitys aequata. As a result of these comparisons, we regard Telemachus and Parasciadopitys as representing preservational states of the same natural genus.

\section{A Single Conifer Lineage in the Triassic of Antarctica}

The multiple occurrences of Telemachus throughout the Triassic of Gondwana indicate a widespread stratigraphic distribution. In addition to the morphological and anatomical similarities discussed above, additional information supports the relationship between Telemachus and Parasciadopitys seed cones. Both genera have been repeatedly associated with broad multiveined leaves, Telemachus with compressed leaves of Heidiphyllum and Podozamites (Anderson 1978; Retallack 1981; Yao et al. 1993) and Parasciadopitys with permineralized leaves of Notophytum (Axsmith et al. 1998). On the basis of anatomical, morphological, and cuticular characters, Axsmith et al. (1998) suggested that Heidiphyllum and Notophytum probably represent different preservational modes of the same biological taxon (see also Hermsen et al. 2007). Leaves of Notophytum have been found in the Middle Triassic permineralized peat from the Fremouw Formation, attached to young stems with podocarpaceous-type cross-field pitting in the secondary xylem (Meyer-Berthaud and Taylor 1991). Larger stems and roots with similar wood anatomy are also present in the peat and represent the only axes at this site assignable to the conifers; other taxa have closer affinities with the seed ferns (Meyer-Berthaud et al. 1993; Taylor 1996) or the cycad Antarcticycas (Smoot et al. 1985; Hermsen et al. 2009). In summary, available data do not support the placement of all these organs in different families. The wide geographic and stratigraphic occurrence of these Antarctic conifer taxa prevents us from suggesting a whole-plant reconstruction. However, it is possible to hypothesize that most of these genera were part of the same lineage. Seed cones of this lineage were of the Telemachus-Parasciadopitys type, while Heidiphyllum-Notophytum represent the leaves and stems. An anatomically preserved pollen cone, Leastrobus fallae Hermsen, Taylor et Taylor (2007), also from the permineralized peat, was suggested to have voltzialean affinities. Comparison with Parasciadopitys and Notophytum shows that while Leastrobus axes have a simpler organization with no secondary xylem, the possibility that the three morphogenera were produced by the same natural taxon cannot be excluded on the basis of the anatomical characters known to date (Hermsen et al. 2007).

\section{Telemachus and Other Transitional Conifers}

The genus Telemachus is related to several conifers from the Permian and Triassic of both Southern and Northern hemispheres, which formed part of a group termed the transitional conifers that included the Voltziaceae and Lebachiaceae (Miller 1977; Retallack 1981; Yao et al. 1993; Rothwell et al. 2005). This concept, which originated in the detailed studies of Florin (1938-1945, 1951, 1954), has as its foundation the presence of ovuliferous scales that are multilobed distally. The basis of Florin's model can be explained if two hypotheses are accepted, i.e., the monophyletic status of the conifers and the position of the Cordaitales as the common ancestor for all coniferophytes and conifers. In this context, the multilobed scale complex of the transitional conifers was interpreted as representing a series of transitional steps between the dwarf shoots of the cordaitaleans and some basal coniferophytes, and, finally, to the totally fused cone complexes present in some living and fossil conifers (Miller 1977). The interpretation of these intermediate stages is based on features such as morphology and degree of fusion of bract and scale, number of scale lobes, and number and morphology of ovules.

In the Southern Hemisphere, the Triassic genus Rissikia (Townrow 1967a) and the Permian-Triassic Voltziopsis (Townrow 1967b) have multilobed ovuliferous scales, which have 
been used to relate these forms with Telemachus. However, Voltziopsis has bifurcate bracts and a less lignified OC, while Rissikia is characterized by broader trifid bracts and three scale lobes per OC. In addition, there are numerous differences in cone and ovuliferous-scale size and morphology.

A larger number of genera with lobed scales have been described from Permian and Triassic localities in the Northern Hemisphere. These include Pseudovoltzia (Schweitzer 1963; Clement-Westerhof 1987), Swedenborgia (Harris 1935; Bugdaeva 1995), Borysthenia and Cycadocarpidium (Stanislavskii 1976), Glyptolepis (Florin 1951; Miller 1977), and Tricanolepis (Miller 1977). The principal differences used to distinguish these genera include the relative size and number of scale lobes and bracts, as well as the type of leaves associated with the cones (Anderson 1978; Axsmith et al. 1998). Among these forms, only Swedenborgia has scales with five distal lobes and is also associated with multiveined leaves. The principal difference between Telemachus and Swedenborgia is the presence of long bracts in most Telemachus species and the absence in Swedenborgia; however, it is now clear that bract morphology and length are probably highly homoplastic characters, even among the different species of Telemachus.

Axsmith et al. (1998) suggested that Aethophyllum, Borysthenia, Cycadocarpidium, Swedenborgia, and Telemachus belong to a single group of transitional conifers, probably related to the Podocarpaceae. The relationship of these genera has been based on the morphology and anatomy of the leaves, but their seed cones show several differences from extant podocarps. Some genera, such as Rissikia and Stalagma (Zhou 1983), were interpreted as having transitional morphologies between the voltzialeans and the Podocarpaceae (Miller 1977;
Retallack 1981; Axsmith et al. 1998). The hypothesized relationship between Telemachus and Parasciadopitys might also suggest inclusion of the latter in the transitional conifers, though it was previously included in the Taxodiaceae.

It is clear that when considering only isolated organs in these transitional conifers, it is possible to reach contradictory conclusions about their affinities. For example, if the hypothesis herein is correct, seed cones assignable to the same natural genus (Telemachus-Parasciadopitys) were previously thought to have affinities with two conifer families, the Podocarpaceae and the Taxodiaceae. Representatives of the transitional conifers are also surely likely to combine characters found in different extant conifer families. In addition, since the evolution of vegetative, pollen, and seed organs does not necessarily occur at the same pace (i.e., mosaic evolution), different parts of the same plant might be considered more or less derived. Vegetative remains (wood and leaves) and pollen cones from the Triassic of Antarctica have also been assigned to different natural groups, as noted above. If we consider the anatomically preserved remains, they currently include one seed cone assigned to the Taxodiaceae ( $P$. aequata; Yao et al. 1997), one pollen cone with similarities to the voltzialeans ( $L$. fallae; Hermsen et al. 2007), and a single type of stem and leaves assigned to the Podocarpaceae (Notophytum krauselii; Axsmith et al. 1998). Although these organs could be interpreted as indicating the presence of three families of conifers (with organs recognized for all of them), they might also represent a single group combining characteristics of all three families. This simple example underscores the necessity of using whole-plant concepts to fully understand the taxonomy and evolution of the transitional conifers.

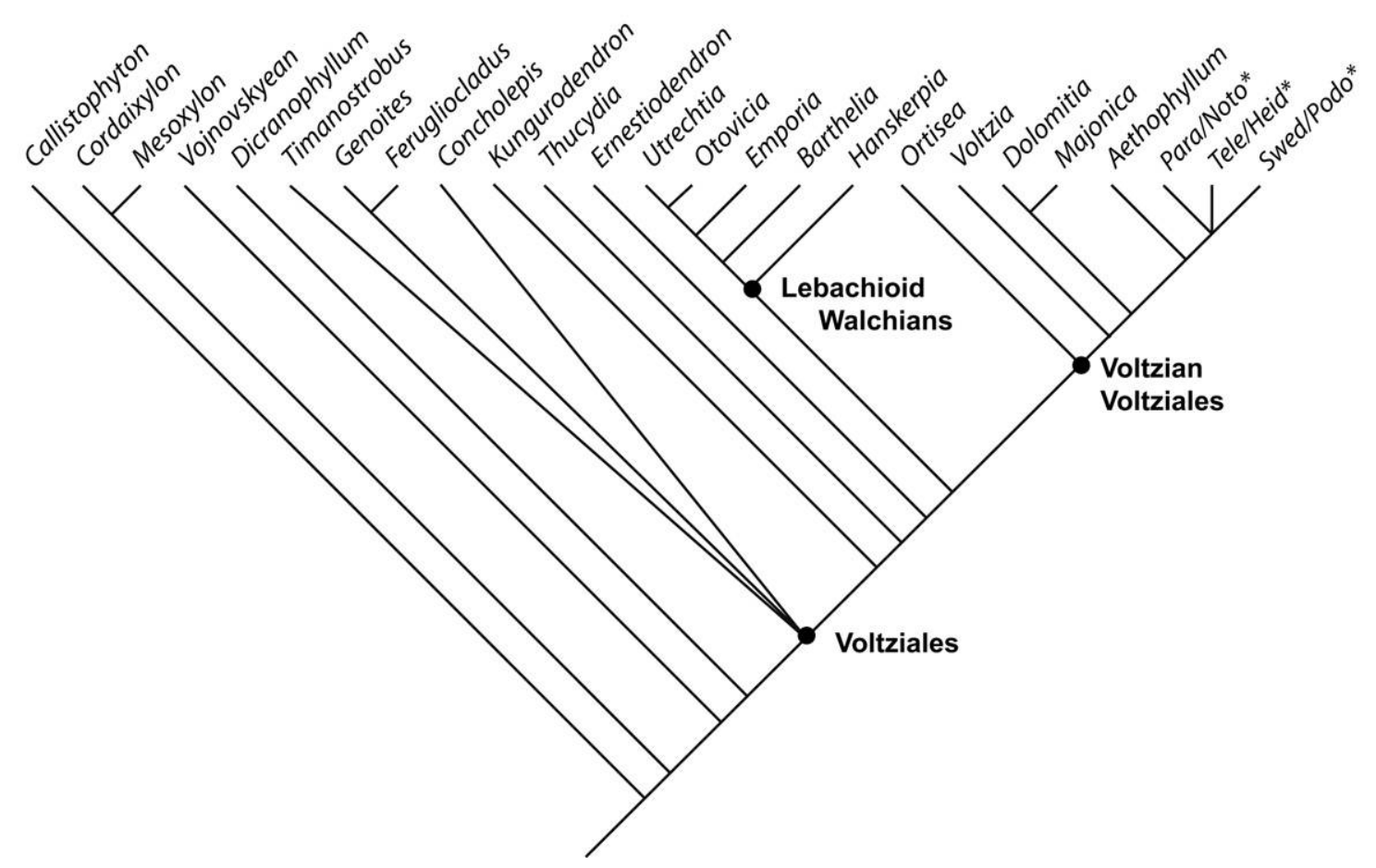

Fig. 7 Strict consensus of two most parsimonious trees of 184 steps found in our phylogenetic analysis. Asterisks indicate the taxa added in this contribution to the matrix of Rothwell et al. (2005). Note the placement of Telemachus in the voltzian clade. 


\section{Phylogenetic Considerations and the Basal Relationships of Telemachus}

For our analysis, the phylogenetic position of the composite taxa T. elongatus-Heidiphyllum elongatum, P. aequataN. krauselii and Swedenborgia cryptomerioides-Podozamites schenkii was analyzed by using the matrix published by Rothwell et al. (2005) with the addition of these three taxa (appendix). This matrix was originally developed to test the relationships between walchian and other ancient conifers and coniferophytes and includes several late Paleozoic taxa and the single Triassic species Aethophyllum stipulare Brongniart, a voltzian conifer from the Triassic of France (GrauvogelStamm and Grauvogel 1975). As a result, only the basal relationships and origin of Telemachus and the related forms will be discussed. Our cladistic analysis yielded two most parsimonious trees, each of 184 steps, with the strict consensus tree presented in figure 6. The inclusion of the new taxa in the analysis did not, however, modify the relationships obtained by Rothwell et al. (2005). It is interesting to note that the three Triassic composite taxa constitute a monophyletic group in the consensus tree (fig. 7), supported by two unambiguous synapomorphies: the presence of leaves that are constricted at the base and the presence of vegetative scales on the adaxial surface of the OCs (characters 9 and 52; Rothwell et al. 2005). As a result of this topology, the theory that Telemachus and Parasciadopitys are related species cannot be rejected. The internal relationships of this clade, however, are not resolved in the strict consensus tree. This is probably the result of a lack of detailed characters that may represent morphological variability within this group. Additional characters and a more extensive taxon sampling are needed to resolve the relationships of this and other voltzian conifers. The unresolved group that includes Telemachus is supported by the presence of multiveined leaves and the larger number of ovules per OC (characters 7 and 49; Rothwell et al. 2005) and appears as sister to A. stipulare. Several other characters also provide support for the position of the Triassic forms as part of the voltzian lineage, such as the presence of bracts that are morphologically different from the vegetative leaves and the presence of determinant fertile aggregations (cones), as well as other characteristics of the leaves and seed cones. The topology obtained in this article increases our knowledge about the evolution of early Mesozoic transitional conifers, a group that was worldwide in distribution and has been considered to be morphologically intermediate between the Paleozoic conifers and their modern relatives (Axsmith and Taylor 1997).

One of the primary goals of paleobotany, especially in those areas in which the focus of the research is directed at understanding the biology of the organism, is the reconstruction of the complete plant. This is typically accomplished by demonstrating anatomical relationships among different organs and different stages of preservation and by repeated and unique co-occurrence. The discovery of anatomical features in the seed cone Telemachus has provided an important initial step in defining the most complete Triassic conifer from Gondwana. The description of several additional components of this plant (e.g., embryos, mycorrhizae) will make it possible to propose a complete reconstruction of this high-latitude conifer in the near future.

\section{Acknowledgments}

We thank Michael Krings and Rubén Cúneo, who helped with the early development of the ideas included in this contribution. We also thank Rudolph Serbet, who provided assistance in some aspects of fossil preparation, and Sara Taliaferro, for the reconstructions. This manuscript was improved through critical comments from three anonymous reviewers. This research was supported by the National Science Foundation (OPP-0635477 to E. L. Taylor and T. N. Taylor).

\section{Literature Cited}

Anderson HM 1978 Podozamites and associated cones and scales from the Upper Triassic Molteno Formation, Karoo Basin, South Africa. Palaeontol Afr 21:57-77.

Anderson JM, HM Anderson 1983 Palaeoflora of southern Africa: Molteno Formation (Triassic). Pt 2. Dicroidium. Balkema, Rotterdam.

2003 Heyday of the gymnosperms: systematics and biodiversity of the Late Triassic Molteno fructifications. National Botanical Institute, Pretoria.

$\rightarrow$ Axsmith BJ, TN Taylor 1997 The Triassic conifer seed cone Glyptolepis. Rev Palaeobot Palynol 96:71-79.

$\rightarrow$ Axsmith BJ, TN Taylor, EL Taylor 1998 Anatomically preserved leaves of the conifer Notophytum krauselii (Podocarpaceae) from the Triassic of Antarctica. Am J Bot 85:704-713.

Axsmith BJ, TN Taylor, EL Taylor, LD Boucher, GW Rothwell, NR Cúneo 1995 Triassic conifer seed cones from the Lashly Formation, southern Victoria Land. Antarct J US 30:44-46.

$\rightarrow$ Axsmith BJ, TN Taylor, EL Taylor, NR Cúneo 2000 New perspectives on the Mesozoic seed fern order Corystospermales based on attached organs from the Triassic of Antarctica. Am J Bot 87:757768.
Bugdaeva EV 1995 Podozamites and Swedenborgia from the Lower Cretaceous of Transbaikalia. Paleontol J 29:105-109.

$\rightarrow$ Clement-Westerhof JA 1987 Aspects of Permian palaeobotany and palynology. VII. The Majonicaceae, a new family of Late Permian conifers. Rev Palaeobot Palynol 52:375-402.

$\rightarrow$ Escapa I, B Axsmith, EL Taylor, TN Taylor 2010 Modifications of the transfer technique for studying complex plant structures. Rev Palaeobot Palynol 159:62-68.

$\rightarrow$ Farabee M, EL Taylor, TN Taylor 1989 Pollen and spore assemblages from the Falla Formation (Upper Triassic), Central Transantarctic Mountains, Antarctica. Rev Palaeobot Palynol 61:101-138.

Florin R 1938-1945 Die Koniferen des Oberkarbons und des unteren Perms. Palaeontographica 85B:1-729.

1951 Evolution in cordaites and conifers. Acta Horti Bergiani 15:285-388.

1954 The female reproductive organs of conifers and taxads. Biol Rev 29:367-389.

$\rightarrow$ Goloboff P, J Farris, K Nixon 2008 TNT, a free program for phylogenetic analysis. Cladistics 24:774-786.

$\rightarrow$ Grauvogel-Stamm L, L Grauvogel 1975 Aethophyllum Brongniart 1828, conifer (non Equisetale) from the Voltzia Sandstone (upper 
Bunter) of the Vosges (France): a preliminary account. Geobios 8: 143-146.

$\rightarrow$ Hammer WR, JW Collinson, RA Askin, WJ Hickerson 2004 The first Upper Triassic vertebrate locality in Antarctica. Gondwana Res 7:199-204.

Harris TM 1935 The fossil flora of Scoresby Sound East Greenland. 4. Ginkgoales, Coniferales, Lycopodiales and isolated fructifications. Medd Gronl 112:3-172.

1937 The fossil flora of Scoresby Sound East Greenland. 5. Stratigraphic relations of the plant beds. Medd Gronl 112:3-104.

$\rightarrow$ Hermsen EJ, EL Taylor, TN Taylor 2009 Morphology and ecology of the Antarcticycas plant. Rev Palaeobot Palynol 153:108-123.

$\rightarrow$ Hermsen EJ, TN Taylor, EL Taylor 2007 A voltzialean pollen cone from the Triassic of Antarctica. Rev Palaeobot Palynol 144:113-122.

$\rightarrow$ Kyle RA 1977 Palynostratigraphy of the Victoria Group of south Victoria Land, Antarctica. N Z J Geol Geophys 20:1081-1102.

Kyle RA, JM Schopf 1982 Permian and Triassic palynostratigraphy of the Victoria Group, Transantarctic Mountains. Pages 649-659 in C Craddock, ed. Antarctic geoscience. International Union of Geological Sciences Series B-4. University of Wisconsin Press, Madison.

Lutz AI 2006 Estudio de la paleoflora de la Formación Carrizal (Triásico Superior), Cuenca de Marayes-El Carrizal, San Juan, Argentina. PhD thesis. Universidad Nacional del Nordeste, Corrientes, Argentina.

$\rightarrow$ Meyer-Berthaud B, TN Taylor 1991 A probable conifer with podocarpaceous affinities from the Triassic of Antarctica. Rev Palaeobot Palynol 67:179-198.

Meyer-Berthaud B, TN Taylor, EL Taylor 1993 Petrified stems bearing Dicroidium leaves from the Triassic of Antarctica. Palaeontology 36:337-356.

$\rightarrow$ Miller CN 1977 Mesozoic conifers. Bot Rev 43:218-280.

Morel EM 1994 El Triásico del Cerro Cacheuta, Mendoza (Argentina).

I. Geología, contenido paleoflorístico y cronoestratigrafía. Ameghiniana 31:161-176.

$\rightarrow$ Nielsen SN 2005 The Triassic Santa Juana Formation at the lower Biobío River, south central Chile. J S Am Earth Sci 19:547-562.

$\rightarrow$ Retallack G 1981 Middle Triassic megafossil plants from Long Gully, near Otematata, north Otago, New Zealand. J R Soc N Z 11:167-200. $\rightarrow$ Rothwell GW, G Mapes, GR Hernández-Castillo 2005 Hanskerpia gen. nov. and phylogenetic relationships among the most ancient conifers (Voltziales). Taxon 54:733-750.

$\rightarrow$ Schulz C, T Stützel 2007 Evolution of taxodiaceous Cupressaceae (Coniferopsida). Org Divers Evol 7:124-135.

Schweitzer H-J 1963 Der weibliche Zapfen von Pseudovoltzia liebeana und seine Bedeutung für die Phylogenie der Koniferen. Palaeontographica 113B:1-29.

$\rightarrow$ Smoot EL, TN Taylor, T Delevoryas 1985 Structurally preserved fossil plants from Antarctica. I. Antarcticycas, gen. nov., a Triassic cycad stem from the Beardmore Glacier area. Am J Bot 72:1410-1423.

Stanislavskii FA 1976 Middle Keuper flora of the Donets Basin. National Academy of Sciences of Ukraine, Kiev.

$\rightarrow$ Taylor EL 1996 Enigmatic gymnosperms? structurally preserved Permian and Triassic seed ferns from Antarctica. Rev Palaeobot Palynol 90:303-318.

Taylor EL, TN Taylor, NR Cúneo, A Archangelsky, H Kerp 1996 Seed fern reproductive organs from the Shackleton Glacier area. Antarct J US 31:27-29.

Townrow JA 1967a On Rissikia and Mataia: podocarpaceous conifers from the lower Mesozoic of southern lands. Pap Proc R Soc Tasman 101:103-131.

- 1967b On Voltziopsis, a southern conifer of Lower Triassic age. Pap Proc R Soc Tasman 101:173-188.

Walton J 1923 On a new method for investigating fossil plant impressions or incrustations. Ann Bot 37:379-391.

1928 On the structure of a Paleozoic cone-scale and the evidence it furnished of the primitive nature of the double conescale in the conifers. Mem Proc Manch Lit Philos Soc 73:1-6.

$\rightarrow$ Watson J, HL Fisher, NA Hall 1987 A new species of Brachyphyllum from the English Wealden and its probable female cone. Rev Palaeobot Palynol 51:169-187.

$\rightarrow$ Yao X, TN Taylor, EL Taylor 1993 The Triassic seed cone Telemachus from Antarctica. Rev Palaeobot Palynol 78:269-276.

—_ 1997 A taxodiaceous seed cone from the Triassic of Antarctica. Am J Bot 84:343-354.

Zhou Z 1983 Stalagma samara, a new podocarpaceous conifer with monocolpate pollen from the Upper Triassic of Hunan, China. Palaeontographica 185B:56-78. 